\title{
Ayat Al Quran (Jasa) Sebagai Mahar Pernikahan Menurut Perspektif Islam dan Imam Mazhab
}

\author{
Muhammad Habib, Ramadhania \\ Sekolah Tinggi Agama Islam Jam'iyah Mahmudiyah, Tanjung Pura \\ M_Habib@staijm.ac.id
}

\begin{tabular}{l}
\hline INFO ARTIKEL \\
\hline Diterima \\
2 September 2020 \\
Direvisi \\
15 November 2020 \\
Disetujui \\
15 Desember 2020
\end{tabular}

Kata Kunci:

Mahar Pernikahan; Perspektif Islam; Imam Mazhab

\section{ABSTRAK}

Pernikahan adalah sesuatu yang sakral dan sangat suci, ia adalah impian setiap anak dan perempuan. Tapi untuk mewujudkan itu tidak mudah dan sembarangan, seperti di pernikahan, ada pilar dan kondisi yang harus dipenuhi, jika kekurangan salah satu pilar atau kondisi maka menurut kesepakatan para ulama figh pernikahan tersebut tidak sah. Harus diakui bahwa bentuk pernikahan yang paling dominan pada masa pra-Islam adalah bersifat kontraktual. Tidak pernah ada konsep pernikahan yang sakramental di tanah Arab. Islam mempertahankan bentuk pernikahan ini dengan melakukan perbaikan tertentu. Bentuk pernikahan yang paling populer adalah pernikahan yang berlaku setelah revolusi Islam. Salah satu unsur utama yang ada dalam pernikahan adalah permasalahan mahar, maka tanpa mahar ikatan pernikahan tidak sempurna. Mahar adalah suatu pemberian yang wajib diberikan oleh seorang pria terhadap seorang wanita baik berupa benda, harta ataupun jasa yang disebut dalam akad nikah sebagai pernyataan persetujuan antara pria dan wanita untuk hidup bersama sebagai istri. Mahar sunah disebutkan jumlah atau bentuk barangnya dalam akad nikah. Apa saja barang yang ada nilai (harga) nya sah untuk dijadikan sebagai mahar. Dalam masyarakat pra-Islam status mahar adalah sebagai uang ganti pemeliharaan yang diberikan orang tua si wanita, kemudian dirubah oleh Islam menjadi pemberian calon suami kepada calon istri yang penuh dengan ketulusan sebagai simbol dan tanda cinta kasih sayang untuk membentuk keluarga yang penuh ketentraman, kedamaian dan ikatan yang utuh di antara pasangan suami dan istri. Untuk memahami hadits-hadits tentang mahar dengan ayat al-Qur'an secara mendalam, maka dalam penelitian ini menggunakan beberapa metode yang ditawarkan oleh Musahadi Ham dalam bukunya "Evolusi Konsep Sunnah", yaitu metode Kritik Historis, Kritik Eidetis yang memuat tiga poin penting meliputi analisis isi, analisis sosio historis dan analisis generalisasi dan metode yang terakhir adalah Kritik Praktis. Islam tidak menetapkan kadar mahar atau jenis mahar yang harus dikeluarkan oleh calon suami untuk istrinya, besar dan bentuk mahar senantiasa hendaknya berpedoman kepada sifat kesederhanaan. Nas al-Qur'an hanya memberikan keterangan bahwa mahar adalah pemberian yang wajib diberikan oleh suami kepada istrinya tanpa adanya batasan tertentu. 


ABSTRACT
Marriage is something sacred and very holy, he is the dream of every
boy and girl. But to realize it is not easy and carelessly, as in a
marriage, there are the pillars and the conditions that must be met,
if the lack of one of the pillars or condition then according to the
agreement fiqh scholars such marriages invalid. It should be
recognized that the most dominant form of marriage in pre-Islam is
contractual. There was never a concept of sacramental marriage in
the Arab lands. Islam maintains this form of marriage by making
certain repairs. The most popular form of marriage is a marriage
that prevailed after the Islamic revolution. One of the main elements
that exist within marriage is dowry problems, then without dowry
marriage bond is not perfect. Mahar is a gift that must be given by a
man against a woman in the form of objects, property or services
referenced in the ceremony as a statement of consent between man
and woman to live together as a wife. Mahar sunna amount or form
of goods mentioned in the marriage contract. Any item that is the
value (price) it is legitimate to be used as a dowry. In pre-Islamic
society status dowry is a money exchange for maintenance given the
parents of the woman, then changed by Islam be giving prospective
husband to the bride full of sincerity as a symbol and sign of love
affection to establish a family full of tranquility, peace and intact
bond between husband and wife couple. To understand the hadiths
about the dowry with verses of the Koran in depth, in this study
using several methods offered by Musahadi Ham in his book "The
Evolution of Concepts Sunnah", the method of Historical Criticism,
Criticism Eidetis that contains three key points include content
analysis, socio-historical analysis and generalization analysis and
the latter method is the Practical Criticism. Islam does not specify
levels of dowry or mahr types that must be issued by a husband for
his wife, and form large dowry should always be guided by the
nature of its simplicity. Nas al-Qur'an only testified that dowry is a
gift that must be given by a husband to his wife without certain
restrictions.
Islamic Perspective,

\section{Pendahuluan}

Salah satu dari usaha Islam ialah memperhatikan dan menghargai kedudukan wanita, yaitu memberinya dan menghargai kedudukan wanita itu dengan cara memberinya hak untuk memegang urusannya. Pada Jahiliyah hak perempuan dihilangkan dan disia-siakan, sehingga walinya dengan semena-mena dapat menggunakan hartanya, dan tidak memberikan kesempatan untuk mengurus hartanya dan menggunakannya. Lalu Islam datang menghilangkan belenggu ini kepada setiap wanita dan diberi mahar, sebagai bentuk penghormatan kepada wanita (Sayyid Sabiq, 1981: 53). Kata "Mahar" berasal dari bahasa Arab dan telah menjadi bahasa Indonesia terpakai. Dalam Kamus Besar Bahasa Indonesia mendefenisikan mahar itu dengan "pemberian wajib berupa uang atau barang dari mempelai laki-laki kepada mempelai perempuan ketika dilangsungkan akad nikah". Hal ini sesuai dengan tradisi yang berlaku di Indonesia bahwa mahar diserahkan ketika berlangsungnya akad nikah (Ramulyo, 1996: 200). 
Mahar atau maskawin adalah harta pemberian dari mempelai laki-laki kepada mempelai perempuan yang merupakan hak si isteri (Nasiri, 2010: 13). Mahar merupakan satu di antara hak isteri yang didasarkan atas Kitabullah, Sunnah Rasul dan Ijma' kaum muslimin (Mughniyah, 2007: 364). Kata mahar yang menjadi bahasa Indonesia berasal dari bahasa Arab yaitu al mahr, jamaknya al muhur atau al muhurah. Kata yang semakna dengan mahar adalah as sadaq, nihlah, faridhah, ajr, hiba', uqr., 'ala'iq, thaul dan nikah (Nurjannah, 2003: 23). Mazhab Hanafi mendefenisikan sebagai sesuatu yang didapatkan seseorang perempuan akibat akad pernikahan atau persetubuhan. Mazhab Maliki mendefenisikannya sebagai sesuatu yang diberikan kepada seorang isteri sebagai imbalan persetubuhan dengannya. Mazhab Syafi'i mendefenisikannya sebagai sesuatu yang diwajibkan sebab pernikahan atau persetubuhan, atau lewatnya kehormatan perempuan dengan tanpa daya, seperti akibat susuan dan mundurnya para saksi. Mazhab Hambali mendefenisikan sebagai pengganti dalam akad pernikahan, baik mahar ditentukan di dalam akad, atau ditetapkan setelahnya dengan keridhaan kedua belah pihak atau hakim (Wahbah, 2007: 23).

Dalam tradisi Arab sebagaimana yang terdapat dalam kitab fiqih, mahar itu meskipun wajib, namun tidak mesti diserahkan waktu berlangsungnya akad nikah dalam arti boleh diberikan waktu akad nikah dan boleh sesudah berlangsungnya akad nikah itu. Definisi yang diberikan oleh ulama waktu itu sejalan dengan tradisi yang berlaku waktu itu. Oleh karena itu, definisi tepat yang dapat mencakup keduanya kemungkinan itu adalah: "pemberian khusus yang bersifat wajib berupa uang atau barang yang diserahkan mempelai laki-laki kepada mempelai perempuan ketika atau akibat dari berlangsungnya akad nikah"( Ghozali, 20: 21).

\section{Metode Penelitian}

Penelitian ini dilakukan secara empirik melalui pendekatan kualitatif dengan metode studi kasus sebagai "alat atau cara" mengeksplorasi hal baru yang berkaitan dengan objek penelitian (Yin, 2009). Adapun fokus pembahasan penelitian ini yaitu Ayat Al Quran (Jasa) Sebagai Mahar Pernikahan Menurut Perspektif Islam Dan Imam Mazhab. Penelitian ini dilakukan sejak Januari-April 2021.

Pengumpulan data penelitian diperoleh dengan teknik observasi, wawancara, dan studi dokumentasi. Selanjutnya, data tersebut dianalisa melalui teknik (1) reduksi data sebagai proses pemilahan data, (2) penyajian data secara naratif, dan (3) menarik simpulan.

Terakhir, validitas data penelitian diuji dan penjaminannya melalui teknik triangulasi. Triangulasi yang dimaksud sebagai bentuk penjaringan data, yang selanjutnya dikomparasikan antara data yang satu dengan data lainnya (wawancara informan yang satu, dengan informan lainnya) (Creswell, 2009; Assingkily, 2021). Dalam konteks ini, 2 (dua) aspek triangulasi yang dibandingkan, yaitu metode dan sumber data. Dengan demikian, data yang disajikan dan telah memperoleh simpulan valid dan sesuai dengan konteks penelitian.

\section{Hasil dan Pembahasan}

Setelah kritik historis dan proses pemahaman (kritik eidetis) dilakukan, masih ada masalah lagi berkaitan dengan penumbuhan makna hadits kepada realitas kehidupan kekinian. Konstruk rasional 
universal atau tujuan moral-sosial universal yang diperoleh dari proses generalisasi tersebut diproyeksikan ke dalam realitas kehidupan kekinian sehingga memiliki makna praksis bagi penyelesaian problematika hukum dan kemasyarakatan kekinian. Ia harus ditubuhkan (embodied), meminjam bahasa Rahman dalam konteks sosio-historis yang konkrit di masa sekarang (Musahadi , 2000: 159).

Berkaitan dengan ini diperlukan kajian yang cermat terhadap situasi kekinian dan analisis berbagai realitas yang dihadapi, sehingga kita dapat menilai situasi kekinian dan mengubah kondisinya sejauh diperlukan dan menentukan prioritas-prioritas baru untuk bisa mengimplementasikan nilai-nilai hadits secara baru pula. Pembahasan tentang mahar ini sangat penting sebagai salah satu upaya untuk menemukan pemahaman yang lebih lengkap tentang status mahar, agar tidak terjadi kesalahpahaman. Sebab ada kesan, bahwa ada diantara sejumlah muslim yang memahami bahwa fungsi mahar adalah sebagai alat tukar atau kepemilikan yang berarti pembelian. Konsekuensinya, mereka merasa berhak melakukan apa saja terhadap istrinya, termasuk di dalamnya hak memarahi semaunya, berbuat apa saja semaunya, bahkan berhak memukulnya dengan alasan sudah menjadi hak milik mutlak sebab sudah dibeli dengan membayar mahar di awal pernikahan mereka.

Mahar adalah termasuk lembaga cabang (sub institution) yang berkaitan dengan soal pernikahan, perbesanan dan kekerabatan. Di berbagai masyarakatmahar merupakan suatu lembaga yang memerankan sejumlah fungsi keagamaan, perekonomian, kejiwaan, hukum-hukum seterusnya. Mahar inilah yang membedakan mana pernikahan legal dan mana hubungan seks di luar pernikahan.
Kadang-kadang mahar juga membedakan manakah konsekuensi-konsekuensi hubungan seks yang diakui masyarakat, dan mana yang tidak, baik berupa keturunan, hak-hak, kewajiban-kewajiban dan seterusnya.

Kita tahu bahwa proses pernikahan terutama di kalangan masyarakat tradisional memakan waktu yang cukup panjang, dimana kedua belah pihak calon suami istri itu saling bertukar hadiah dan kebanyakan hadiah-hadiah itu dari pihak calon suami dan keluarganya. Hadiahhadiah tersebut ada yang berupa jasa atau sesuatu yang jika dilihat dari segi ekonomi bahkan tidak bernilai apa-apa, sekalipun secara sosiologis mempunyai arti yang cukup besar.

Mahar merupakan suatu kewajiban yang harus dipikul oleh setiap calon suami yang akan menikahi calon istri sebagai tanda persetujuan dan kerelaan untuk hidup bersama sebagai suami istri.Pada umumnya maskawin itu dalam bentuk materi baik berupa uang atau barang berharga lainnya.

Syari'at Islam memungkinkan maskawin itu dalam bentuk jasa melakukan sesuatu, bahkan meskipun hanya berupa lantunan ayat al-Qur'an yang dihafal oleh mempelai laki-laki. Hal ini seperti mahar Nabi Musa ketika menikahi puterinya Nabi Syu'aib berupa jasa menggembalakan kambing selama delapan tahun atau saat Nabi Muhammad SAW menikahi Sofiyah dengan maskawin membebaskan Sofiyah dari status budak maupun ketika Nabi Muhammad SAW menikahkan seseorang dengan mahar berupa hafalan al-Qur'an.

Berdasarkan hasil pemaparan penulis di atas, maka untuk memperjelas uraian dan analisis bab keempat tesis ini, maka kriteria yang dikemukakan para Imam madhab (Abu Hanifah, Maliki, 
Syafi'i dan Ahmad Hambali) dituangkan sebagai berikut:

1. Imam Abu Hanifah (Imam Kamaluddin bin al-Humam) Tidak membolehkan. Karena mahar yang berupa jasa tidak termasuk harta yang tidak boleh mengambil upah darinya, sehingga tidak sah untuk dijadikan mahar, namun darinya wajib dibayar mahar mitsil.

2. Imam Malik Membolehkan Karena jasa patut menjadi mahar, sama halnya dengan harta.

3. Imam Syafi'I Membolehkan Karena mahar yang berupa jasa atau manfaat yang dapat diupahkan dijadikan mahar.

4. Imam Ahmad ibn Hambal Membolehkan Karena mahar berupa manfaat seperti halnya mahar berupa benda, dengan syarat manfaat harus diketahui.

Dari penjelasan di atas tersebut tampak bahwa dalam perspektif Imam Abu Hanifah mengenai mahar mengajarkan al-Qur'an atau melayani istri yang menurut Imam Kamaluddin bin al Humam a Hanafi yang merupakan murid dari Imam Abu Hanifah dalam kitab Syarh Fathul Qadir yaitu:

"Jika seseorang yang merdeka menikah dengan mahar akan melayani istri 1 tahun atau mengajarinya al-Qur'an, maka bagi istri adalah mahar mitsil. Muhammad berkata: bagi istri tersebut adalah harga pelayanan. Jika seorang hamba sahaya menikah dengan izin tuannya dengan mahar melayani istri selama 1 tahun, maka diperbolehkan dan bagi istri mendapat pelayanan suami tersebut".

Penjelasan dari kitab di atas adalah jika seseorang yang merdeka, menikah dengan mahar akan melayani istri selama satu tahun atau mengajarinya alQur'an, maka bagi isteri adalah mahar mitsil. Hukum mengajarkan al-Qur'an sebagai mahar menurut Imam
Kamaluddin bin al-Humam al-Hanafi dengan mengutip Imam Abu Hanifah yaitu bahwa mengajarkan al-Qur'an sebagai mahar adalah fasad (rusak) dan harus mengganti mahar mithil. Alasan hukumnya terdapat dalam kitab Syarh Fathul Qadir karangan Imam Ibnu al-Humam, sebagai berikut:

"Menurut Abu Hanifah, sesungguhnya yang asli diwajibkan adalah mahar mitsil karena mahar mitsil itu yang paling adil, dan kalaupun ada yang mengadakan perpindahan memilih tidak memakai mahar mitsil itu dibolehkan ketika mereka telah memilih mahar musamma, menurut Abu Hanifah itu tidak sah atau rusak karena tidak jelas".

Golongan madzhab Hanafiyah tidak membolehkan mengajarkan al-Qur'an sebagai mahar, karena berdasarkan pendapat mereka bahwa mengambil upah mengajarkan al-Qur'an adalah haram dan diganti dengan mahar mitsil. Batas minimal mahar adalah 10 dirham, dengan mengemukakan dalil yang diriwayatkan oleh ad-Daruquthni dan alBaihaqi dalam kitabnya yang menyatakan bahwa:

Jangan nikahkan wanita kecuali sekufu' dan jangan mengawinkan wanita kecuali para walinya, dan tidak ada mahar yang kurang dari sepuluh dirham".

Imam Malik mengatakan mahar jasa seperti pengajaran al-Qur'an dan sebagainya, menghuni (memanfaatkan) rumah, atau pelayanan hamba sahaya, patut menjadi mahar, apabila mahar berupa jasa atau manfaat itu terlanjur terjadi.

Ibnu al 'Arabiy salah satu dari murid Imam Malik, mensahkan sesuatu yang bermanfaat dijadikan mahar, seperti membolehkan mengajarkan al-Qur'an sebagai mahar, sama dengan pendapat Imam Syafi'i dan Imam Ahmad bin Hambal. 
Mahar tidak memiliki batas minimum dan batas maksimum. Kaidahnya adalah segala sesuatu yang dapat menjadi harga, baik berupa benda maupun manfaat bisa dijadikan mahar, dan telah dijelaskan bahwa disunahkan mahar tidak kurang dari 10 dirham dan tidak lebih dari 500 dirham. Diperbolehkan menikah dengan mahar manfaat yang diketahui, seperti mengajarkan al-Qur'an.

Imam Syafi'i membolehkan adanya mahar dengan menjahit pakaian, membangun rumah, melayani sebulan, atau mengajarkan al-Qur'an kepada istri, yang merupakan mahar jasa. Menurut Imam Syafi'i, setiap manfaat yang dimiliki dan halal harganya serta mempunyai nilai kesederhanaan pada mahar itu lebih beliau sukai. Beliau memandang sunnah, bahwa tidak berlebih pada mahar.

Hal ini terdapat dalam kitabnya alUmm sebagai berikut:

"Imam asy-Syafi'i berkata: Boleh bahwa wanita itu mengawini seorang lakilaki untuk menjahit kepadanya pakaian atau membangun baginya rumah atau melayani sebulan atau lelaki itu berbuat baginya suatu perbuatan apa saja atau ia mengajarkan al-Qur'an yang disebutkan atau ia mengajarkan bagi wanita itu seorang budak dan yang serupa dengan ini".

Imam Syafi'i berkata bahwa tidak disebut "alaiq" kecuali sesuatu yang bernilai harta walaupun sedikit dan tidak dinamakan harta kecuali sesuatu yang bernilai dan bisa diperjual belikan. Seorang merdeka sah menikah dengan seorang wanita dengan mahar melayaninya selama waktu tertentu, atau dengan mahar mendatangkan pelayan merdeka untuk melayani mempelai wanita selama waktu tertentu, lebih-lebih jika yang didatangkan adalah pelayan hamba sahaya. Sah menikah dengan mahar perbuatan yang diketahui seperti menjahit pakaian tertentu, baik ia sendiri yang menjahit atau orang lain, jika pakaian tersebut rusak sebelum dijahit maka mempelai lelaki wajib membayar setengah harga upahnya, meskipun ia mengeluarkan talak sebelum berhubungan suami isteri.

Pendapat Imam Syafi'i dan Imam Ahmad Hambali tersebut bila diperhatikan, maka menurut penulis bahwa Imam Syafi'i dan Imam Ahmad Hambali hendak meringankan kaum laki-laki yang ingin menikah dengan mahar non materi yang berupa jasa atau manfaat, dengan tidak memberikan syarat yang sulit yaitu pekerjaan atau setiap sesuatu yang dapat diupahkan atau mendatangkan manfaat yang baik bagi istri maka sah dijadikan mahar.

Tampaknya Imam Syafi'i dan Imam Ahmad Hambali menilai bahwa perkawinan itu jangan dipersulit tapi agar dipermudah termasuk persoalan maskawin yang terkadang menjadi kendala bagi sebagian orang (kaum pria) yang ingin menikah, terutama memberikan mahar yang tidak berupa materi.

Pendapat Imam Syafi'i, Ishaq dan Hasan bin Salih, Imam Ahmad Hambali dan Imam Malik, dalam hal ini upah boleh dijadikan mahar, apabila memang upah yang dijadikan mahar itu ada, sehingga kemanfaatan dari upah (jasa) tersebut menempati posisi mahar. Sedangkan menurut pendapat Imam Hanafi melarang (tidak memperbolehkan) memberikan mahar dengan mengajarkan al-Quran atau upah dari hasil mengajarkan al-Quran, karena tidak sebanding dengan harta.

Islam memberikan hak kepada kaum wanita untuk menuntut mahar dari laki-laki yang akan menikahinya menurut yang dia kehendakinya, tetapi Islam memberikan motivasi bahwa wanita yang 
paling berkah adalah wanita yang ringan maskawinnya.

Mahar sebenarnya memiliki nilai penting dalam perkawinan dan sebagai pemberian yang wajib dalam suatu akad perkawinan, sebagaimana firman Allah QS. an-Nisa' ayat 4:

Artinya: "Berikanlah maskawin (mahar) kepada wanita (yang kamu nikahi) sebagai pemberian dengan penuh kerelaan. kemudian jika mereka menyerahkan kepada kamu sebagian dari maskawin itu dengan senang hati, Maka makanlah (ambillah) pemberian itu (sebagai makanan) yang sedap lagi baik akibatnya."

Menurut analisis penulis, bahwa dari pendapat-pendapat ulama di atas dan dari pembahasan bab-bab sebelumnya, bila ditinjau dari segi non materi (jasa), mahar dengan mengajarkan al-Qur'an, masuk Islam, memerdekakan budak, atau pengajaran ilmu-ilmu agama yang lain dapat mendatangkan banyak keuntungan. Di samping banyak mendatangkan manfaat, menikah dengan mahar tersebut mendatangkan pahala tersendiri bagi suami atau istrinya, yang demikian ini, jauh lebih mulia dibandingkan dengan harta benda yang bernilai jutaan.

Hal ini akan dirasakan bagi merekayang mengerti dan memahami manfaat dari mahar tersebut. Jika diukur dengan materi, maka tidak bisa disepadankan nilainya, yang terpenting kedua belah pihak atas dasar sukarela, sehingga boleh saja memberikan mahar materi berupa harta atau mahar non materi berupa jasa atau manfaat seperti mengajarkan al Qur'an.

Biasanya mahar berupa barangbarang seperti tadi, yakni barang-barang yang tinggi nilainya dari sudut sosiologis dan ritual, meski tidak berarti apa-apa jika ditinjau dari segi ekonomi, akan tetapi memiliki kebanggaan dan kepuasan tersendiri di sebagian kalangan. Selain itu, mahar kadang-kadang bisa berupa jasa secara cuma-cuma, seperti tinggal pada keluarga mempelai perempuan dan bekerja disana beberapa waktu yang ditentukan oleh adat. Tetapi ada pula mahar yang berupa sesuatu materi, tetapi nilai moral atau nilai sosialnya lebih tinggi dari pada nilai materialnya. Seperti ternak di Afrika Timur (kawasan Cattle Complex), dimana kualitas dan kuantitas ternak dijadikan ukuran dari kedudukan sosial seseorang. Ternaklah yang dibayarkan sebagai mahar, dan ternak pula yang dibayarkan sebagai denda kriminal. Pada masyarakat tersebut ternak yang dibayarkan itu bukanlah merupakan proses jual-beli antara laki-laki dan perempuan (Taufiq, 1987: 209).

Islam telah menetapkan mahar (mas kawin) sebagai kewajiban seorang pria (suami) terhadap wanita (istri), sebaliknya ia merupakan hak bagi seorang wanita. Meskipun demikian keduanya boleh memanfaatkannya secara bersama-sama. Allah telah menetapkan usaha untuk mencari nafkah sebagai kewajibanbagi seorang pria. Sebaliknya, mencari nafkah tidak ditempatkan sebagai kewajiban bagi seorang wanita, tetapi hanya sekedar boleh saja, dan jika memang ia menghendaki maka boleh melakukannya, jika ia tidak menghendakinya, boleh tidak melakukannya.

Adapun hadits-hadits di atas mengandung pengertian bahwa mahar tidak memiliki ukuran minimal dan maksimal. Segenggam kurma, cincin yang terbuat dari besi, dan sepasang alas kaki bisa sah untuk dijadikan mahar. Selain itu, jika seorang wanita ridla dengan ilmu yang dimiliki oleh suaminya atau ridla dengan hafalan al-Quran suaminya, baik seluruh atau sebagian al-Quran untuk dijadikan mahar, maka hal itu dibolehkan karena 
ilmu atau hafalan al-Quran sang suami dapat mendatangkan manfaat bagi istrinya, sebagaimana diperbolehkannya sang tuan menikahi budaknya dan maharnya adalah dengan kebebasannya dari perbudakan, dan itu mahar yang lebih baik sehingga Ummu Sulaim lebih memilih dan mengambil manfaat dari keislaman Abu Talhah dan ia rela menyerahkan dirinya kepada Abu Talhah asal mau masuk Islam. Keislaman Abu Talhah lebih ia cintai dari pada harta yang diberikan kepadanya, karena pada dasarnya disyaratkannya mahar agar sang istri bisa mengambil manfaat dari mahar yang diberikan oleh suami tersebut. Ucapan Rasulullah SAW., yang mengatakan, Bila wanita itu memakainya, maka kamu tidak akan dapat memakai apa-apa, adalah bila ia memakai kain (sarung) itu dengan sempurna. Bila tidak, maka dapat diketahui tentang sulitnya kehidupan laki-laki tersebut dan ia sendiri tidak memiliki pakaian, sehingga bila pakaian itu dibagi menjadi dua, maka tidak akan dapat menutupi tubuhnya dengan sempurna.

Ada juga kemungkinan bahwa yang dimaksud tidak ada tersebut adalah tidak sempurna, berdasarkan kebiasaan orang Arab yang sering meniadakan sesuatu hanya karena ia tidak sempurna. Dengan demikian, maksud dari kata tidak sempurna di atas adalah bila pakaian (kain) tersebut disobek menjadi dua bagian, maka tidak dapat digunakan untuk menutupi seluruh badan baik bila dipakai oleh wanita itu ataupun oleh laki-laki itu sendiri. Redaksi perkataan Rasulullah di atas menunjukkan tentang kebijaksanaan Rasulullah SAW., terhadap kemaslahatan kaumnya dan menunjukkan kelembutan beliau terhadap mereka.

Dari segi pembuktian dalil, perkataan di atas membuktikan bahwa Rasulullah SAW., memperbolehkan laki-laki itu untuk memberikan cincin yang terbuat dari besi sebagai mahar. Mahar bisa sah dengan segala sesuatu yang masuk dalam kategori harta. Secara tersirat, perkataan di atas mengandung perintah untuk segera bergegas mencari sesuatu untuk diberikan kepada wanita yang akan menjadi istrinya tersebut, karena jika beliau menghendaki bentuk mahar yang dapat mensahkan akad nikah, maka beliau cukup dengan menetapkan bahwa mahar dalam tanggungannya, sehingga dibolehkan untuk melaksanakan akad nikah dan tidak perlu lagi beliau meminta laki-laki itu untuk bergegas dalam mendapatkan sesuatu.

Dengan demikian, perkataan di atas menunjukkan bahwa Nabi tidak menginginkan dengan ucapannya itu sesuatu yang bisa mensahkan akad. Lafal "Saya tidak mempunyai apa-apa", mencakup makna segala sesuatu, termasuk didalamnya adalah sebiji gandum. Namun lafal itu dilanjutkan dengan kata "Carilah sesuatu walaupun sebuah cincin yang terbuat dari besi".

Artinya: "Sahal Ibnu Saad Radliyallaahu 'anhu berkata: Nabi Shallallaahu 'alaihi wa Sallam pernah mengawinkan seorang laki-laki dengan seorang perempuan dengan maskawin sebuah cincin dari besi (Al-Bukhori, 2001: 249)."

Dalam hadits tersebut beliau menyebutkan sesuatu yang lebih tinggi nilainya, sebab cincin dari besi lebih berharga dari pada biji gandum.

Jika kita analisis tentang batasan mahar yang harus dikeluarkan, maka dapat disimpulkan bahwa jika kadar mahar ditentukan jumlahnya, maka seolah-olah perempuan seperti barang dagangan yang dipasang tarif dan etika perdagangannya. Perbuatan semacam ini berarti menyalahi hakikat pensyariatan mahar itu sendiri, yaitu untuk mengangkat harkat dan 
martabat wanita, memuliakan kehormatannya serta meninggikan kedudukannya.

Di samping itu juga dapat menimbulkan efek negatif baik bagi wanita itu sendiri maupun bagi laki-laki yang ingin meminangnya. Dampak yang lebih parah lagi adalah akan mengundang banyak kejahatan dan kemaksiatan serta merusak dunia pernikahan. Bahkan bisa menimbulkan kesan bahwa yang halal itu lebih sulit dicari dari pada yang haram, akhirnya bagi laki-laki yang tipis tingkat keimanannya akan lebih gampang bersenang-senang secara "liar" dengan wanita dari pada menikah, karena biasanya wanita pelacur itu lebih murah dan meriah, sedangkan wanita yang halal itu lebih mahal dan payah serta wajib dinikahi.

Seruan Islam untuk menikah kepada mereka yang mampu, adalah demi terpeliharanya umat manusia, demi keselamatan dan jaminan untuk mendapatkan ketentraman, cinta dan kasih sayang. Oleh karena itu, Islam tidak menentukan batas minimal dan maksimal mahar dalam pernikahan. Hal ini diserahkan kepada permufakatan kelonggaran dan adat istiadat yang berlaku di setiap daerah tersebut.

Dalam hal ini terdapat dua golongan yang berbeda dalam memberikan argumen tentang adanya batas minimal dan tidak adanya batasan dalam mahar. Bagi aliran yang memberikan ketentuan kadar mahar yang harus diberikan adalah dengan mengqiyaskan kepada nisab potong tangan dalam pencurian, karena masing-masing merupakan ketentuan syara' yang menghalalkan anggota tubuh. Menurut mereka nisab pencurian yang mewajibkan potong tangan adalah sepuluh dirham. Maka ukuran itulah yang bisa menghalalkan kehormatan wanita. Sedangkan kelompok yang berpendapat bahwa kadar mahar minimal seperempat dinar emas atau tiga dirham perak juga mengqiyaskan hal ini pada nisab potong tangan dalam pencurian karena ada kesamaan di antara keduanya. Keanggotaan wanita merupakan anggota tubuh, tangan juga anggota tubuh yang dihalalkan dengan ukuran harta tertentu. Dalam mengqiyaskan mahar dengan nisab pencurian, Malikiyah sependapat dengan golongan Hanafiyah (Ibn Rusyd, 2000: 14).

$$
\text { Berbeda dengan golongan }
$$

sebelumnya, golongan Syafi'iyah dan Hanabilah berargumentasi bahwa tidak ditetapkannya kadar mahar dalam pernikahan, ini adalah berdasarkan alQuran, Sunnah Nabi SAW. dan perkataan para sahabat serta dalil rasio. Dalam alQuran surat an-Nisa' (4) : 24 disebutkan:

Artinya: dan (diharamkan juga kamu mengawini) wanita yang bersuami, kecuali budak-budak yang kamu miliki (Allah telah menetapkan hukum itu) sebagai ketetapanNya atas kamu. dan Dihalalkan bagi kamu selain yang demikian (yaitu) mencari isteriisteri dengan hartamu untuk dikawini bukan untuk berzina. Maka isteri-isteri yang telah kamu nikmati (campuri) di antara mereka, berikanlah kepada mereka maharnya (dengan sempurna), sebagai suatu kewajiban; dan Tiadalah mengapa bagi kamu terhadap sesuatu yang kamu telah saling merelakannya, sesudah menentukan mahar itu. Sesungguhnya Allah Maha mengetahui lagi Maha Bijaksana.

Dari ayat di atas sesungguhnya Allah SWT mengaitkan halalnya wanita dalam ayat tersebut dengan memberikan harta, dan harta itu bisa sedikit ataupun banyak. Karena harta dalam ayat ini adalah mutlak, tidak dikaitkan dengan ukuran tertentu, dan tidak ada dalil syariat yang sah yang bisa dijadikan alasan untuk mengaitkannya dengan ukuran tertentu seperti lima atau 
sepuluh dirham. Oleh karena itu, dengan mengamalkan ayat tersebut berarti setiap benda yang disebut sebagai harta, sah dijadikan sebagai mahar dalam pernikahan baik sedikit maupun banyak.

Dengan demikian, ayat al-Quran yang dijadikan dalil oleh golongan Syafi'iyah dan Hanabilah menjelaskan bahwa syariat Islam tidak menentukan kadar atau jumlah benda yang akan dijadikan mahar dalam pernikahan. Kalimat ibtagu bi amwalikum pada ayat di atas menunjukkan bahwa mencari harta merupakan sesuatu yang tanpa batas. Kalau banyak maka banyak pula pahala yang diperolehnya, demikian juga sebaliknya (Nur Jannah, 2003: 76).

Sekalipun Islam tidak menentukan batas minimal dan maksimal mahar, tetapi tetap memperingatkan jangan sampai mahar itu membelenggu, berlebih-lebihan dan memberatkan seseorang di luar batas kemampuannya. Islam adalah agama yang wasit dan adil, karena berlebih-lebihan dan mempermahal mahar akan mengakibatkan kaum muda lebih suka membujang atau menyebabkan mereka terpaksa menari hutang dan akibatnya terbukalah pintu berbagai problem keluarga sesudah menikah.

Mahar dalam Islam terlebih dahulu mempunyai fungsi keagamaan, dan juga fungsi-fungsi kejiwaan seperti fungsinya sebagai bukti adanya perhubungan, perjanjian, ikatan yang kuat, terlaksananya persetubuhan dalam suatu ikatan cinta yang teguh sebelum memiliki fungsi ekonomi yang bersifat material. Islam menyuarakan agar mahar itu yang sederhana saja, jangan mahal-mahal. Hal ini terbukti dengan dinikahkannya seorang sahabat dengan mahar mengajarkan beberapa ayat al-Quran yang telah dihafalnya oleh Rasulullah SAW sebagaimana hadits yang diriwayatkan oleh Sahl di atas.
Berdasarkan analisis isi dan realitas, maka ditemukan makna tekstual hadits dan signifikasi konteksnya dengan realitas historis masa Nabi. Dengan melihat pemaknaan tekstual dan kondisi sosiohistoris munculnya hadits tentang mahar dengan ayat al-Quran dalam pernikahan, dapat ditarik sebuah pesan inti yang terkandung di dalamnya, bahwa apa yang tertera dalam hadits tentang sahabat Nabi SAW yang menikah dengan mahar beberapa ayat dari al-Quran tidak dapat dipahami secara tekstual. Kalimat"Saya nikahkan kamu dengannya dengan ayat alQuran yang kamu hafal". mengandung arti bahwa Nabi SAW menikahkan sahabat tersebut dengan maksud supaya sahabat tersebut mengajarkan beberapa ayat tersebut kepada istrinya, tidak sematamata membacakan akan tetapi lebih dari itu, suami diwajibkan untuk mengajarkannya sebagai mahar atas istrinya.

Dalam hal ini, terdapat beberapa perbedaan pendapat dalam menentukan jumlah ayat yang dimaksud, yakni minimal 20 ayat yang harus dihafal oleh calon mempelai laki-laki sebagai mahar untuk calon mempelai wanita seperti yang diriwayatkan oleh Abu Hurairah, dan selainnya menyebutkan seluruh hafalan yang dimiliki calon mempelai laki-laki, yakni surat al-Baqarah dan sebagian yang lain menyebutkan sepuluh ayat atau hanya surat-surat pendek(al-Asqalani, tt: 207).

Adapun alasan diberikannya batasan dalam mengajarkan ayat al-Quran sampai 20 ayat, disebabkan para wanita muslimah pada waktu itu umumnya sangat mudah menangkap pelajaran, terlebih lagi mereka adalah orang Arab yang memiliki bahasa seperti bahasa calon suami yang akan mengajarkan ayat kepadanya.

Sebagian alasan yang menyebutkan bahwa hadits-hadits di atas adalah hadits 
yang dikhususkan bagi Nabi Muhammad SAW atau yang mengatakan bahwa haditshadits itu adalah mansukh (terhapus), atau mengatakan bahwa yang dilakukan oleh penduduk Madinah adalah bertentangan dengan hadits-hadits tersebut, maka semua ucapan itu adalah ungkapan yang tidak memiliki dalil dan dasar yang bisa membantah kebenaran yang ada (Shalil, 2002: 26).

Menurut al-Qurtubi kata "mengajarkan kepadanya" adalah nas yang ditujukan untuk mengajarkan kepada istrinya. Namun konteks tersebut menguatkan bahwa kata tersebut ditujukan untuk masalah pernikahan. Hal ini tidak dapat dikaitkan dengan alasan memuliakan laki-laki tersebut karena hadits tersebut dengan jelas mengungkapkan akan sebaliknya.

Seandainya dipermasalahkan, bagaimana mengajarkan al-Quran tersebut dianggap sah padahal tidak diajarkan kepada wanita itu? Jika hal ini dapat dianalogikan maka sama halnya permasalahan di atas dengan mengajarkan lewat tulisan sebagai mahar itu dianggap sah sedangkan wanita itu sendiri tidak belajar darinya. Sebenarnya yang terjadi ikhtilaf adalah pada orang yang menjadikan sebuah kemanfaatan sebagai mahar, apakah disyaratkan bagi seseorang yang mengajarkan untuk menyesuaikan kecerdasan orang yang diajari ataukah tidak.

Dalam hal ini, sama juga dengan upah yang boleh dijadikan mahar, bila memang upah yang dijadikan mahar itu ada, sehingga kemanfaatan dari upah tersebut menempati posisi mahar. Demikianlah pendapat imam Syafi'i, Ishaq dan Hasan bin Salih. Sedangkan menurut pendapat Imam Hanafi dan imam Malik melarang (tidak memperbolehkan) memberikan mahar dengan mengajarkan al-Quran atau upah dari hasil mengajarkan al-Quran. Pendapat ini merupakan pendapat golongan ulama yang menggunakan ra'y. Sedangkan Imam Ahmad bin Hanbal memakruhkan mahar tersebut.

Dimakruhkan mahar dengan ayat alQuran atau mengajarkan al-Quran hanya bila calon suami masih mampu memberikan harta yang lain. Namun bila memang ia tidak mampu memberikan yang lain maka tidaklah makruh baginya. Sepertinya alasan Rasulullah SAW mendahulukan makruh demikian ini adalah agar tidak ada persetubuhan antara lakilaki dan perempuan sebelum memberikan sesuatu sebagai maharnya.

Disamping itu disunnahkan juga bagi pasangan yang hendak menikah untuk tidak menjalankan akad nikah kecuali setelah adanya maskawin, karena ia dapat meredam pertengkaran dan lebih bermanfaat bagi seorang istri dan bila memang terjadi talaq sebelum bersetubuh, maka bagi seorang suami wajib membayar mahar yang telah disebutkan. Tetapi bila tidak menyebutkan mahar ketika melakukan akad nikah, maka bagi sang istri tidak wajib mendapatkan mahar tersebut, namun yang wajib baginya adalah mut'ah (pemberian).

Di zaman sekarang ini masih banyak orang tua yang menikahkan anak gadisnya hanya mempertimbangankan materi belaka. Seakan-akan anak gadisnya adalah barang dagangan yang mendatangkan keuntungan besar dan harta melimpah bagi keluarganya. Mahar dalam Islam bukanlah berarti sebagai nilai tukar seorang anak perempuan kepada suaminya dalam sebutan jual beli.

Gadis yang cantik, berpendidikan tinggi atau memiliki pekerjaan bergengsi biasanya membuat sang ayah menjadi tertipu oleh diri sendiri. Dengan congkak, menuntut laki-laki yang meminang anak 
gadisnya untuk membayar mahar (mas kawin) yang mahal. Hal ini sangat memberatkan bagi pemuda yang hendak melamar anak gadisnya. Dengan bangga, seorang ayah mengatakan bahwa dirinya telah menafkahi anak gadisnya sejak kecil hingga dewasa. Ia mengeluarkan biaya yang tidak sedikit sampai anak gadisnya menjadi seperti sekarang ini. Bagaimana sang pemuda bisa memberikan mahar yang demikian memberatkan dirinya tersebut? Tuntutan ayah si gadis melemahkan nyalinya untuk melamar. Hal ini jauh dari ajaran yang telah dibawa oleh Nabi Muhammad SAW.

Gejala materialisme telah merebak dan menyusup dalam angan-angan setiap orang. Tidak jarang kita jumpai mereka yang hendak menikah dijadikan korban 'perdagangan' orang tua, dengan memanfaatkan kesempatan untuk meraih laba (keuntungan) sebanyak-banyaknya. Para orang tua bahkan si gadis sendiri menetapkan mas kawin setinggi mungkin, melihat latar belakang calon menantunya dengan ukuran golongan, besarnya gaji, dan sebagainya. Sementara pertimbangan akhlak, agama dan ketakwaan, yang lebih memudahkan terlaksananya perkawinan, lepas dari perhatiannya sama sekali.

Yang demikian ini sama halnya dia menentang keluhuran akhlak dan kemuliaan hidup yang berlandaskan prinsip Ilahi. Akibatnya kemajuan masyarakat pun akan ikut terlambat. Ruh mereka yang luhur, akhlaknya yang agung dan budi pekertinya yang sopan santun tersumbat oleh sikap segolongan manusia yang materialistis.

Golongan materialis tersebut adalah golongan manusia yang terpesona oleh kilauan harta benda yang menipunya. Mereka lebih berpegang kepada tradisi yang tidak ditetapkan oleh Allah. Hatinya jauh dari jiwa syariat Islamiyah yang lebih memiliki hikmah yang tinggi. Hati dan kalbunya tidak memahami mutiara-mutiara hikmah agama yang mengatakan: Artinya: "Jika datang kepada kalian seorang laki-laki yang engkau ridhai agama dan akhlaknya, maka nikahkanlah dia (dengan anak perempuanmu). Jika kalian tidak melakukan hal ini, maka akan terjadi fitnah dan kerusakan besar di atas bumi."

Hadits yang diriwayatkan oleh Sahl di atas menunjukkan bahwa mahar dalam Islam bukanlah sekedar soal ekonomi, tetapi lebih mulia dan lebih tinggi dari itu. Mahar adalah sebagai peneguh kekuatan akad, penegas betapa luhurnya kedudukan wanita dan bukti atas kejujuran niat dari kedua belah pihak, laki-laki dan perempuan untuk membangun sebuah kehidupan rumah tangga.

Islam memberikan hak kepada wanita untuk memegang urusannya, termasuk dalam memanfaatkan maharnya. Hal ini merupakan salah satu upaya Islam untuk mengangkat harkat dan martabat wanita serta menghargai kedudukannya, karena pada zaman Jahiliyah hak perempuan telah dihilangkan dan disiasiakan. Pada masa itu para orang tua dapat dengan leluasa mempergunakan harta tersebut sesuai dengan keinginannya sendiri tanpa memperdulikan hak-hak anak gadisnya.

Peristiwa yang pernah terjadi pada masa Nabi SAW tentang mahar berupa cincin dai besi ataupun mahar berupa jasa mengajarkan beberap ayat al-Quran pada istrinya, hingga sekarang masih dapat kita temui khususnya di negara Indonesia tercinta ini. Mahar dengan cincin, uang atau barang yang lainnya yang hampir seluruhnya disertai dengan seperangkat alat shalat dan juga sebuah kitab suci alQuran banyak kita temui pada beberapa tahun belakangan. 
Hal ini, seakan-akan menjadi suatu keharusan atau kewajiban tersendiri di setiap pernikahan pada akhirnya, kebiasaan ini menjadi suatu tradisi yang seakan-akan tidak afdal kalau tidak dilaksanakan. Sebagaimana ketentuan yang telah dikemukakan di atas tentang kewajiban mengajarkan beberapa ayat al-Quran yang dijadikan mahar, maka secara tidak langsung kewajiban seorang suami yang memberikan mahar berupa "seperangkat alat shalat" yang termasuk kitab suci alQuran di dalamnya akan lebih berat. Yang demikian ini disebabkan karena azas pemberian mahar itu sendiri adalah berazaskan manfaat, mahar apapun yang diberikan oleh suami atau yang diminta oleh istrinya pada intinya adalah harus mendatangkan manfaat, baik berupa harta benda ataupun berupa jasa. "Seperangkat alat shalat" termasuk kitab suci tidak dikatakan berfaedah jika selesai akad tidak ada tindak lanjut (follow up) dalam memanfaatkan barang-barang tersebut. Selesai akad, al-Quran dan peralatan shalat diletakkan begitu saja pada tempatnya, seolah-olah al-Quran tidak berarti sama sekali.

Kedua benda tersebut tidak akan menjadi manfaat jika tidak digunakan sebagaimana mestinya, yaitu sebagai alat dan sarana untuk beribadah kepada Allah dengan baik dan benar. Jika kita merujuk pada ajaran yang telah dibawa Nabi SAW di atas, maka seorang suami yang memberikan mahar berupa seperangkat alat shalat dan sebuah kitab suci al-Quran mempunyai kewajiban mengajarkan kepada istrinya tentang tata cara membaca al-Quran ataupun tentang isi dari pada alQuran itu sendiri. Begitu juga terhadap alat shalat atau yang lebih dikenal dengan sebutan mukena (rukuh), suami wajib mengajarkan kepada istrinya bagaimana shalat yang baik dan benar.
Diriwayatkan dari Usman bin Affan r.a bahwa Rasulullah SAW bersabda: Artinya: "Sebaik-baik kalian adalah yang mempelajari al-Quran dan mengajarkannya."

Diutarakan oleh Abu Abdullah Muhammad bin Ismail dalam kitab Sahihnya, yang merupakan kitab sumber paling valid setelah al-Quran al-karim.

Ditinjau dari segi non materi, mahar dengan mengajarkan al-Quran dapat mendatangkan banyak keuntungan. Di samping banyak mendatangkan manfaat, menikah dengan mahar mengajarkan alQuran mendatangkan pahala tersendiri bagi suami atau istrinya. Yang demikian ini, jauh lebih mulia dibandingkan dengan harta benda yang bernilai jutaan. Hal ini akan dirasakan bagi mereka yang mengerti dan memahami manfaat dari sebuah kitab suci al-Quran dan juga alat shalat. Jika diukur dengan materi, maka tidak bisa disepadankan nilainya. Inilah rahasinya, mengapa sahabat yang menikah dengan beberapa ayat al-Quran diharuskan untuk mengajarkan kepada istrinya. Yang menjadi permasalahan kemudian adalah bagaimana dengan suami yang tidak begitu mengerti tentang bacaan dan juga tata cara beribadah yang baik dan benar. Ini bisa terjadi pada pasangan yang baru masuk Islam (muallaf) atau orang yang notabene muslim akan tetapi dia kurang begitu mengerti masalah agama secara mendalam.

Untuk mengatasi masalah yang demikian ini sebenarnya banyak cara yang dapat dilakukan, antara lain adalah dengan mendatangkan seorang guru agama atau seseorang, baik laki-laki ataupun perempuan yang berkompeten dalam urusan agama sebagai kompensasi atas suami yang kurang begitu mengerti masalah agama atau belum fasih dalam melafalkan ayat-ayat al-Quran. Hal ini dilakukan demi tanggungjawab suami atas 
mahar yang telah diberikan kepada istrinya, dan konsekuensinya benda-beda tersebut harus mendatangkan kemanfaatan terhadap istri yang menerimanya.

Mahar tidak hanya sebagai simbol kelegalan pernikahan semata. Untuk itu, istri berhak menuntut suami untuk mengajarkannya atau paling tidak mendatangkan seorang guru untuk dirinya, karena mahar adalah hak penuh seorang wanita. Dengan demikian, "Seperangkat alat shalat" yang dijadikan mahar tersebut tidak hanya sebagai simbol atas kelegalan hubungan suami istri saja, akan tetapi ini sebagai salah satu bukti bahwa seorang suami sebagai imam dalam rumah tangga harus memberikan suri tauladan yang baik kepada istrinya.

Sedangkan al-Quran yang dijadikan sebagai pelengkap kehalalan pernikahan tersebut tidak menjadi sia-sia. Sebagai pegangan bagi umat muslim, kitab suci alQuran tidak bisa digunakan semaunya dengan tujuan yang tidak pasti, apalagi digunakan hanya karena mengikuti trend yang berlaku di masyarakat semata, tanpa mengetahui esensi dari pemberian al-Quran itu sendiri. Al-Quran adalah mukjizat paling hebat yang diperoleh Nabi SAW., dengan perjuangan yang panjang dan melelahkan, maka selayaknya kita sebagai penganut agama Nabi Muhammad SAW. menjaga dan memeliharanya agar perjuangan yang telah dilakukan oleh Nabi SAW dan para sahabatnya tidak aus karena pergeseran zaman dan tradisi yang berkembang pada saat ini.

Bila dicermati secara umum, nashnash hadits telah datang kepada kita dengan gambaran yang seolah-olah dapat memperdulikan batas minimal mahal dan tidak juga batas maksimalnya, kecuali hanya menyebutkan bahwa mahar haruslah sesuatu yang mempunyai nilai tanpa melihat besar dan kecilnya. Maka Islam membolehkan mahar dalam bentuk cincin dari besi, jasa mengajarkan al-Quran atau sejenisnya. Yang penting kedua belah pihak rela atas mahar tersebut.

Pada kenyataannya, bahwa manusia itu berbeda tingkat ekonominya, sebagian dari mereka kaya dan sebagian besar miskin. Ada orang mempunyai harta melebihi kebutuhan hidupnya dan sebaliknya ada juga yang tidak mampu memenuhinya. Karena itu harga mahar yang harus dibayarkan seorang calon suami kepada calon istrinya sangat ditentukan oleh kemampuannya atau kondisi ekonominya. Islam memberikan hak kepada kaum wanita untuk menuntut mahar dari laki-laki yang akan menikahinya menurut yang dia kehendakinya, tetapi Islam memberikan motivasi bahwa wanita yang paling berkah adalah wanita yang ringan maskawinnya. Dalam satu riwayat disebutkan: Rasulullah SAW bersabda: Artinya: "Sesungguhnya pernikahan yang paling agung adalah pernikahan yang paling murah maharnya."

Pada masyarakat Arab Jahiliyah, mas kawin dianggap harta milik wali perempuan. Jumlah maskawin bervariasi sesuai dengan tingkat pendidikan, jabatan pekerjaan, kekayaan, dan status sosial anak laki-laki. Hal ini juga masih berlaku di luar Jawa (Sumatra) di mana seorang perempuan harus membayar calon suami sesuai dengan tingkat dan derajat pendidikannya, tetapi hanya berlaku di beberapa daerah saja.

Maskawin adalah pemberian suami kepada istri yang merupakan unsur positif dalam hubungan suami-istri, tulang punggung keluarga dan sembarang pemberian, akan tetapi adalah sebagai pertanda bagi masa depan keluarga itu sendiri, dimana suami memimpin istri karena suami memberikan belanja 
kepadanya dan istri menyadari bahwa dia hidup di bawah naungan suami.

Mahar yang diberikan kepada istri bukanlah harga dari wanita dan bukan pula sebagai pembelian wanita itu dari orang tuanya, akan tetapi pensyariatan mahar tersebut merupakan salah satu syarat yang dapat menghalalkan hubungan suami istri antara keduanya yaitu hubungan timbal balik dengan senang hati dan penuh kasih sayang dengan meletakkan status kepemimpinan dalam rumah tangga secara tepat dan bertanggung jawab.

Dengan adanya kewajiban memberikan mahar kepada istri, maka terbentanglah tanggung jawab yang besar dari suami untuk memberikan nafkah di dalam kehidupan rumah tangga secara layak. Sayyid Qutb menjelaskan masalah kepemimpinan ini dengan sejelas-jelasnya. Menurut beliau Allah SWT telah menciptakan manusia, laki-laki dan perempuan, suami istri berdasarkan kaidah universal dalam bangunan alam ini.

Dia menjadikan di antara fungsifungsi istri itu adalah mengandung, melahirkan dan menyusui serta memelihara buah dari hubungan antara dirinya dengan suaminya. Ini adalah fungsi yang agung, di samping penting.

Fungsi-fungsi yang demikian ini bukanlah fungsi yang ringan dan mudah, tidak dapat ditunaikan tanpa persiapan organis, psikologis dan mentalitas yang dalam yang tertanam dalam eksistensi wanita. Maka adil pulalah bila pihak suami diberi tanggung jawab untuk memenuhi kebutuhan-kebutuhan pokok dan juga perlindungan bagi si istri agar istri dapat menunaikan fungsinya yang penting itu.

Dengan demikian, maskawin merupakan suatu pelatihan bagi suami untuk menjalankan fungsi-fungsinya di masa datang, sebelum keluarga itu benarbenar berdiri, disamping merupakan latihan bagi istri menjalankan fungsifungsinya di masa datang, yaitu tunduk kepada kepemimpinan suaminya. Oleh sebab itu, maka Allah memerintahkan kepada jama'ah muslimah untuk membantu orang yang terhalang menikah secara halal karena kekurangan harta, khususnya dalam masalah mahar.

Melalui analisis yang telah penulis lakukan, maka mahar bukanlah sesuatu yang mudah dan juga tidak bisa dikatakan sesuatu yang sukar. Dalam artian segala sesuatu yang dijadikan sebagai mahar terdapat konsekuensinya, karena sedikit ataupun banyaknya mahar yang diberikan pada intinya kembali kepada kemanfaatan benda atau jasa itu sendiri.

Dengan demikian, jika mahar yang diberikan adalah berupa jasa seperti mengajarkan al-Quran atau mengajarkan ilmu-ilmu agama yang lainnya, baik masalah ibadah atau masalah yang terkait dengan ubudiyah, maka hal ini bisa dilakukan dengan bertahap.

Dengan adanya ketentuan yang diajarkan oleh Nabi SAW kepada sahabat yang menikah dengan hafalan ayat-ayat dari al-Quran di atas untuk mengajarkan kepada istrinya, maka bagi pasangan yang menikah dengan mahar seperangkat alat shalat, harus lebih berhati-hati dalam memberikan mahar karena setiap pemberian yang diberikan terdapat konsekuensi sendiri-sendiri. Tidak asal meminta dan memberikan mahar semata, tetapi lebih kepada tujuan dan manfaat dari benda atau jasa itu sendiri. Dengan begitu, diharapkan dapat terhindar dari hal-hal yang menyimpang dari ajaran agama, serta lebih dapat menjunjung tinggi ketentuan agama yang telah dibawa oleh Nabi Muhammad SAW.

Nabi mengizinkan sahabat menikah dengan mengajarkan beberapa ayat dari alQuran karena Nabi memuliakan atas 
hafalan sahabat tersebut. Dengan demikian, tidak selayaknya al-Quran kita jadikan sebagai trend dalam memberikan mahar kepada calon istri. Memberikan mahar dengan "seperangkat alat shalat", akan membawa kebaikan dan mendatangkan kemaslahatan bagi mereka yang memahami akan kegunaan dan keagungannya, kecuali mereka yang memberikan mahar "seperangkat alat shalat" hanya sebagai tradisi semata. Hal ini karena kemuliaan dan keagungan al-Quran sebagai kitab suci umat muslim.

\section{Kesimpulan}

Berdasarkan uraian yang telah dipaparkan tentang ayat al-Quran sebagai mahar dalam pernikahan dengan kajian ma'anil hadits dapat disimpulkan sebagai berikut:

1. Secara tekstual hadits tentang ayat alQuran sebagai mahar dalam pernikahan di atas menjelaskan bahwa Nabi mengizinkan sahabat menikahi seorang wanita dengan mahar beberapa ayat alQuran yang telah dihafalnya. Namun, setelah penulis melakukan penelitian, maka hadits di atas tidak bisa dipahami secara tekstual, karena banyak terdapat penjelasan yang menunjukkan bahwa sahabat tersebut tidak hanya membacakan ayat-ayat yang telah dihafal dihafalnya, akan tetapi sahabat tersebut mempunyai kewajiban untuk mengajarkan ayat-ayat tersebut kepada istrinya. Disamping itu, hadits di atas juga bersifat universal, artinya hadits di atas dapat diterapkan oleh siapapun, tidak hanya berlaku oleh sahabat saja akan tetapi berlaku untuk seluruh umat Muhammad dan berlaku pada masa Nabi hingga pada masa sekarang ini. (berlaku untuk siapa saja, dimana saja, dan kapan saja).
2. Dengan mengamati beberapa pernikahan yang terjadi di masa sekarang ini, khususnya di Indonesia proses pernikahan cukup beragam dan cenderung memakan waktu lama. Dengan perkembangan itu, secara otomatis mahar yang digunakan juga ikut berkembang baik dari segi jumlah ataupun dari segi jenisnya. Bermacam bentuk mahar yang digunakan pada masa sekarang ini, mulai dari seperangkat alat shalat, uang tunai, cincin, hingga rumah megah dapat kita jumpai. Pada prinsipnya apapun yang dijadikan mahar dalam pernikahan tersebut, adalah segala sesuatu yang dapat diambil manfaatnya. Meskipun dari nash al-Quran atau hadits secara eksplisit tidak memberikan patokan terhadap jumlah yang lebih diberikan sebagai maskawin, akan tetapi secara implisit dijelaskan bahwa apapun yang dijadikan sebagai mahar itu tidak membebani seorang laki-laki yang hendak melamarnya. Dengan adanya hadits di atas diharapkan dapat membuka wacana baru bagi sebagian kalangan yang selama ini lebih mendewakan harta benda. Tanpa mereka sadari tindakan seperti itulah yang menghambat kelancaran proses pernikahan anak-anak mereka. Sesungguhnya Allah memberi kemudahan bagi mereka yang lemah dalam hal materi dan kaya akan kebaikan (agama dan akhlak yang baik).

\section{Bibliografi}

Abu Abdillah Muhammad bin Ismail AlBukhori, Shahih Bukhari, juz 3, Surabaya: Al-Hidayah, 2001.

Ahmad Al-Musayyar, Sayyid, Islam Bicara Soal Seks, Percintaan \& Rumah Tangga, Kairo Mesir: Erlangga, 2008. 
Ali, Abdul Mukti, Agama dan Masyarakat, Yogyakarta: Kurnia Kalam Semesta, 1993.

Arikunto, Suharsimi, Penelitian Tindakan Kelas, Jakarta: Bumi Aksara, 2008.

Az-Zuhaili, Wahbah, Fiqih Islam Wa Adilatuhu, Damaskus: Darul Fikir, 2007.

Departemen Agama RI, Al-Qur'an dan Terjemahannya, Bandung: Diponegoro, 2005.

Djubaidah, Neng, Pencatatan Perkawinan \& Perkawinan Tidak Dicatat, Jakarta: Sinar Grafika, 2010.

Ghozali, Abdul Rahman, Fiqih Munakahat, Jakarta: Prenada, 2003.

Hammudah 'Abd. Al 'Ati, Keluarga Islam, Surabya: Bina Ilmu, 1984.

Ibnu Rusyd, Tarjamah Bidayatul Mujtahid, Jilid II, Semarang: As-Syifa', 1990.

Imam Muslim, Shohih Muslim Jus 5, Beirut: Dar al-Kutub Al-Ilmiyah, 1994.

Istibsyaroh, Hak-Hak Perempuan, Jakarta: Teraju, 2004 .

Khallaf, Abdul Wahhab, Ilmu Ushul Fikih, Jakarta: Pustaka Amani.

Mardani, Hukum Perkawinan Islam, Yogyakarta: Graha Ilmu, 2011.

Mughniyah, Muhammad Jawad, Fiqh Lima Madzhab, Jakarta: Penerbit Lentera, 2007.

Nasiri, Hebohnya Kawin Misyar, Surabaya: Al Nur, 2010.

Nurjannah, Mahar Pernikahan, Yogyakarta: Prima Shopi, 2003.
Nuruddin, Amiur \& Azhari Akmal Tarigan, Hukum Perdata Islam di Indonesia, Jakarta: Kencana, 2004.

Rahman, Abdul, Doi, Perkawinan Dalam Syariat Islam, Jakarta: Rineka Cipta, 1996.

Ramulyo, Muhamad Idris, Hukum Perkawinan Islam, Jakarta: Bumi Aksara, 1996.

Sabiq, Sayyid, Fiqh Sunnah VII, Bandung: PT Alma'arif, 1981.

Shihab, M. Quraish, Tafsir Al Misbah, vol 2, Jakarta: Lentera Hati, 2000.

Singarimbun, Masri dan Sofian Effendi, eds., Metode Penelitian Survai, Jakarta: Cet. VIII LP3ES, 2007.

Sudijono, Atunas, Pengantar Statistik Pendidikan, Cet. III, Jakarta: CV. Rajawali, 2001.

Syarifuddin, Amir, Hukum Perkawinan Islam di Indonesia, Jakarta: Kencana, 2009.

Thalib, Sayuti, Hukum Kekeluargaan Islam, Jakarta: UI-Press, 1986.

Umar, Nasaruddin, Kodrat Perempuan Dalam Islam, Jakarta: Lembaga Kajian Agama dan Jender, 1999.

Washfi, Muhammad, Mencapai Keluarga Barokah, Yogyakarta: Mitra Pustaka, 2005.

Wasito, Hermawan, Pengantar Metodologi Penelitian, Cet. I, Jakarta: PT Gramedia, 2002. 


\section{Copyright holder :}

Muhammad Habib, Ramadhania (2020).

First publication right :

Action Research Literate

This article is licensed under:

(c) 9 (9) 